\title{
An Indonesian Administrative Tradition Before The Colonization Period
}

\author{
Andi Ahmad Yani \\ Dept. of Administrative Science \\ Hasanuddin University \\ MakassarIndonesia \\ aayani@unhas.ac.id
}

\begin{abstract}
This paper aims to explore an Indonesian administration tradition before the Dutch colonization period, especially in the Bugis empires in the South Sulawesi Province. This paper starts with a brief history of the Bugis kingdoms as a background and further explores the Bugis empires' administration system based on the administrative tradition concept of Painter and Peters. They offer four indicators to explore traditions as a pattern of certain administration, namely: relationship with society, relationship with political institution, laws vs management, and the accountability process. Lastly, this paper examines transformation process of the Bugis administrative tradition from the colonization period through present day.
\end{abstract}

Keywords - administrative tradition, administrative culture, nonwestern public administration, local wisdom, Bugis empire, Indonesian study

\section{INTRODUCTION}

Indonesia is an archipelago country consisting of around eighteen thousand islands; about nine hundreds of them are permanently populated. In the cultural context, Indonesia has approximately three hundred ethnic groups and local languages. This cultural pluralism was mainly formed by many ancient kingdoms that existed roughly from the $5^{\text {th }}$ Century to the $19^{\text {th }}$ Century ${ }^{[3]}$.

Historians agreed that the Kingdom of Kutai and the Kingdom of Tarumanegara were the first kingdoms in Indonesia ${ }^{[3][4]}$. Some Chinese sources which made from the Tang Dynasty (A.D 618-906) and a stone inscription which was found in the Kalimantan (Borneo) island stated that the Kingdom of Kutai was existed in A.D. $400^{[3]}$. In addition, it was found that the Kingdom of Tarumanegara had controlled part of Java island around A.D 358 - 659, according to some Chinese sources and seven stone inscriptions ${ }^{[3]}$. There were several kingdoms in the Borneo islands around 1600, namely the Sultans of Banjermasin, Sambas, and Sukadana. They all had a strong relationship with the Chinese ${ }^{[4]}$.

In the eastern side of Indonesia, particularly Sulawesi (Celebes) island, some kingdoms had been established around $14^{\text {th }}$ through $19^{\text {th }}$ Centuries, such as the Empire of Buton, the Empire of Goa (Gowa), the Empire of Tallo, the Empire of Luwu, the Empire of Bone, the Empire of Soppeng, and the Empire of Wajo ${ }^{[5]}$. In addition, in the next neighboring island,
Maluku (Moluccas) island, the Sultanate of Ternate was recognized as a powerful kingdom in Eastern Indonesia and ruled most of eastern part of Indonesia and a part of the Southern Philippines from about the $15^{\text {th }}$ until $17^{\text {th }}$ century ${ }^{[4]}$ [5]

Those above kingdoms which previously described are part of hundreds of empires in Indonesian's region that are embedded in the Indonesian societies. Each kingdom might employ different administrative and political systems that were induced by its internal sources like believes, cultures, and geography. It could be enforced by external factors such as colonization process.

These administrative traditions were replaced by various systems. First, the Dutch government introduced the Weberian system during the colonization period. Second, the bureaucratic military system in the Soeharto presidency era, commonly acknowledged as the New Order period. In the last decades, the Indonesian administration system has been primarily influenced by pro-market government system which is promoted by international organizations, like the International Monetary Fund (IMF), the World Bank (WB), the United Nations Development Program (UNDP) and so on. Government system reform within the New Public Management (NPM) approach globally occurs in most developing countries - including Indonesia - and further faces some obstacles to implement this system, which is originally from developed Western countries, into emerging non Western administration systems. The obstacles might be culture barriers ${ }^{[8][2][14]}$ and lack of organization and human resources capacities [9][15][17]. Consequently, most public organizations in developing countries are resistant to change and tend to uphold their traditional values. Consequently, these bureaucrats are more likely to follow the new structure and form of the NPM reform agendas, but they are not intent on making actual change ${ }^{[16]}$

However, these ancient administration systems had employed some pivotal administration methods that are similar to what the modern administration systems also use today. Examples include decentralization, check and balances, and quality-based leadership. Therefore, this study expects that exploring appropriate administration traditions which had been employed in previous times and further reconstructing those values based on current circumstances would lead to 
quality improvement of public administration systems in developing countries.

\section{RESULT AND DISCUSSION}

This section examines ideas and the structure of the governmental system that had been employed by the Bugis domains starting in the $14^{\text {th }}$ century using the administrative tradition concept of Painter and Peters ${ }^{[16]}$. They offer four indicators to explore traditions as a pattern of certain administration, namely: relationship with society, relationship with political institution, laws vs management, and the accountability process ${ }^{[16]}$. These variables will be analyzed throughout this section.

Firstly, Painter and Peters ${ }^{[16]}$ argue that the essential state traditions are determined by the relationship method between state and society. In Europe and North America, the states are commonly categorized in two forms, namely contractual and organic. The contractual system refers to the Lockean concept where this tradition is more concerned with self-governance rather than the concept of state. This tradition is characterized as an inductive-stateless tradition that was primarily adapted in the UK and the $\mathrm{US}^{[12]}$. On the other hand, organic form indicates that state and society are interlocked like two sides of the same coin. The concept of organic form or deductivestateness is commonly applied in most European countries, and arranges the state as the provider of public authority and general interest to ensure equal-access to social and economic resources and redress injustices of the social (market) system $^{[12]}$. The state and society relationship employed in other countries, for example Iran, China or Southeast Asia, might use different methods due to different cultural backgrounds and historical state institutions.

In the Bugis state tradition, based on above noted, it is characterized as the contractual relationship. The society represented by matoa or ulu anang had equal power with the ruler to govern the state. Relationship between society and the ruler was extensively explained in another Bugis ancient manuscript, lontara latoa. Latoa states that :

"The king is less important than the people. The king would not exist without the people, but the people without king is still the people; the people put the king in his place of glory. The people gave life to the king. Therefore, the king is obliged to give his life for the benefit of the people, to protect and respect the rights and property of the people, prevent the people from acts of violence and act as the shelter of the people; The people should clearly know about all the rights and obligations to the government and to other fellow citizens. The government is obliged to explain all these things to the people. That's partly the government's aim to maintain the unity of the people ${ }^{,[11]}$ (p. 446 - 447).

In sum, the Bugis administrative tradition implies contractual traditions where communities (anang) acted in an important role as a function of society. This pattern is different from modern contractual states traditions where society was initially represented by interest groups or political groups.

Secondly, state tradition is also essentially determined by state relationship with political institutions, which implies political influence to the bureaucracy and policy making process $^{[16]}$. However, this variable might be difficult to extensively exercise in the Bugis domains, hence they presumably did not engage in the separation of power system. It thus occurred partly because most political power was determined by the personality of the leaders who holds the power. Thus the political power was more personal than institutional matters ${ }^{[11]}$ (p. 424). As a result, there was relatively limited functional division in administration and political roles. To have a clear description about this circumstance, here is a structural power in the Bugis Kingdom according to lontara Latoa ${ }^{[11]}$.

1. Arung; Arung Mangkau;Arumpone; Datu'. These terms refer to the most important position in the empire who is the King. These figures are placed as a central figure and a symbol of the glory of the whole country and the law.

2. Pabbicara ${ }^{2}$ or To-Mabbicara is described as major power-holders after the king, and somtimes acts as a judge to adjudicate people problems. In other times he functions as an advisor to the king, and on other occasions he serves as the prime minister who manages the government.

3. Pakkattenni-adê', Pampawa adê ' or Puang-adê $\hat{e}^{\prime}$ and sometimes just called $a d \hat{e}^{\prime}$ are described as people who exercise power in the name of king. They sometimes represent the king to serve the interests of the country in general.

In a general sense, they are the board to exercise state functions, where Pabbicara or To-mabbicara becomes a leader in three essential states procesess : (1) representing the interests of the people in policy making process and exercise the legislative power; (2) employ the government's role and served the executive power; and (3) Administrate the court with decisive legal disputes that enroll as the judicial power ${ }^{[11]}$.

In the Wajo Kingdom, there was Arung Mabbicara, which consisted of 30 members that 10 persons represented each three confederation states. Arung Mabbicara is like parliament institution that had two main tasks, namely : (1) maddêttê bicara means formulating and deciding laws and regulations; (2) mattêtta', mappano'-pate' bicara implies proposing suggestions regarding the implementation of legislation to the $\mathrm{King}^{[11]}$.

Another issue in separation of political institutions and the bureaucracy is considering the degree of commitment or competence in public officials and public leaders selection process $^{[16]}$. As previously discussed that there is not political separation in the Bugis kingdoms system in which political and bureaucratic functions could be examined in the same person. This circumstance might result power intervention in 
public leaders and public officials selection process and tend to produce lack commitment and competence in administration system. However, the Bugis domains have been considered this issue and required some standards in selecting process. The Latoa offers four main indicators in selecting empire officials ${ }^{[10]}$, namely:

- Should have abilities to take an appropriate initiative, fear to abuse power and violate people.

- Honest and able to do everything carefully and persistent in doing their tasks.

- Consistent and brave.

- Proficient and do not easily give up if face a challenge (p. 426).

Moreover, Latoa also required all public leaders to be deeply aware and understand seven critical things, namely adê, bêttuang, assertive, fear the God, wari, rapang and bicara. Further Kajaolalido explains those as the following: "A public official who does not know adê would disrupt the trial. An official leader who did not know bêttuang would be easily fooled and that means reduce the integrity of government. A public official who does not fear the God would be very easy to take bribes or abuse power. An official manager who is not aware and assertive would be likely to breach his promises. A government official who does not understand what wari is would be likely to falsify the truth. A public official who does not know about rapang would be prone to retreating his pledge. Then, he tends to become a disloyal official. The official who does not understand what bicara is would be very easily inconsistent"[11](p. 427). Overall, the Bugis empires had certain rules in selecting their public officials and leaders. Although those rules were not very specific in terms of technical skills, they concern attitude values. However, these attitude aspects are very fundamental values in the bureaucracy.

The third component in analyzing administration tradition is the role of public administration that can be differentiated between legal and management patterns ${ }^{[16]}$. In the legal tradition, public administration is a provider of public authority in formulating the legal foundations and ensuring that laws will be well implemented. On the contrary, the principal administrative role in the management tradition refers to organizing and managing state administration in such efficient and effective ways ${ }^{[16]}$.

Considering the Bugis administration traditions, it is quite difficult to compare them to these two modern functions of public administration in terms of personal vs institutional tasks. However, I assume that the essential task of the Bugis public administration is more like the legal form. In earlier discussion is noted that the Latoa required all public officials to deeply understand adê (law) to operate their tasks. This system is similar with the modern legal state systems where hire their public servants who have legal education background ${ }^{[16]}$. Moreover, two strategic positions in the Bugis government, Pabbicara and Pakkattenni-adê', had been executed legal foundation tasks in that period of time.

Lastly, ensuring public bureaucracy to be more accountable is the most critical aspect in all administration systems $^{[16]}$. Accountability system refers to acknowledging a check and balance system to control political and bureaucratic systems through administrative and legalistic accountability forms, such as administrative courts and legislative controls. Another primary approach of accountability is public accountability that relies on public involvement to promote transparency throughout public institutions.

The Bugis administration traditions employed an accountability system through Arung Mabbicara that might exercise legislative functions to control the King and other public officials. The impeachment process briefly noted in the introduction section was a possible consequence when the rulers abused people trust and did not obey adê'.

In addition, public involvement in promoting accountability had been executed also in the Bugis domains but in different patterns. Mattulada ${ }^{[11]}$ identifies five methods that the Bugis people commonly did to protest governmental policy or power violation by the King or King's family (p. 448-449), namely:

1. Mannganro ri-adê; proposing a petition to the King or adê. Groups of adult men and women gathered in an orderly manner in front of the palace. They meet the king to propose their petition to kindly ask the King to do something immediately to solve certain problems. For example, they ask the king to arrange a ritual to bring rain to end the drought. The people understand that droughts occur because the King and public officials made a mistake. Therefore, the king should take responsibility to apologize to the owners of nature (God) and people for their mistakes in order to end the drought;

2. Mapputanê; Such actions to demur or protest to a government policy that might be incriminating. Any person can propose objections that can be delivered either individually or collectively to the King or adế. A group of people who has an objection should come to ulu anang or indo' tau ( community the leaders) and then the leaders assist them to met the King or adê' who declared the policy. If proposing objection in collective way, the ulu anang or indo' tau will meet the King or adê' alone in the name of the people who brought the objection. The other people are gathered in front of Baruga (meeting hall). The decision of the King and $a d \hat{e}^{\prime}$ on their objection will be delivered by ulu anang to them after the meeting.

3. Mallimpo-adê; such a protest action to insist the King or ad $\hat{e}^{\prime}$. This action done when a person or people feel the King or adê did injustice to them. For example, when they did mapputanê but the King has not fixed the problem. Another example is the King failing to punish those who commit violence with an appropriate punishment. People will gather in front of the palace or Baruga and they bring food to stay there for several days until they get the decision that they had expected before. In doing mallimpoadê, everybody involved in this action should not be a weapon.

4. Mabbarata; literally means grief but this term also sometimes used as a means of protesting actions that could result in war. This protest action is usually undertaken by 
the group of relatives or groups of wanua who in principle have felt violated by a King's family member, Emperor's staffs or even the King himself. If mabbarata is intended for the King then the Arung mabbicara will take over the problem and then decide the consequence for the King. If the action is addressed to a Empire official then the King will directly handle the problem. If the problem is not resolved then it might result jallo' (ramp) that threatens the tranquility of the country or public disobedience to the Empire. Mabbarata usually done by a family who has power and respected families network in the community.

5. Mallekkĕ' dapurêng; protest action by the people of moving to another country. This action is usually executed by a big family or members of wanua in the country who choose to fix their problems with the government by leaving the country, having been unable to succeed with other forms of protest. Those who consider to do mallekkĕ' dapurêng state that "we dismiss the king because we are not the part his power anymore. The king should not prohibit this action because those people no longer consider themselves citizens of the country. So, as free people they have right to go wherever they choose as their new country.

\section{CONCLUSION}

The Bugis administration tradition is one of various traditional administration patterns that has been employed for centuries in Indonesia. The Bugis state system had been a practiced contractual pattern but in different context than the Anglo-American administrative traditions. Interestingly, requiring decent knowledge of law (adê) to all public officials shows that the Bugis domains had practiced foundational legal traditions quite similar to those of modern countries. Further, acknowledging impeachment and public protest procedures provides historical factual support that the accountability process was practiced in this ancient society. Another essential aspect of administrative tradition is the relationship between state and political institution; the Bugis administration traditions offered a unique context since most the Bugis domains did not have a separation of power system. There are multiple possible reasons to explain this pattern.

First, they might consider those function attach to personal responsibility rather than institutional responsibility. Those the reasons why Latoa more concern on attitude values instead of technical skills in hiring public officials to ensure that all administrators would not abuse their responsibilities.

Second, it was difficult to find appropriate persons to work in strategic positions, like Pabbicara and Pakkattenni-adê ${ }^{\prime}$ since there was no school or training system in that ancient period to teach and train more people to do those jobs.

Third, in the traditional Bugis society, the learning and training process is part of daily life. Therefore, most Bugis men should go abroad when they have reached a mature age (around 16 years old) to gain more experiences from different places and meet different people. Experiencing various environments without support from family members in the middle of nowhere would force them to learn essential skills to survive and adapt in certain places. After they have succeeded and gained many experiencing then they can go back to their home country. This learning process is commonly called somp $\hat{e}^{\prime}$ and person who do this process named passompê'.

\section{REFERENCES}

[1] A. Djamhuri, "A Case study of governmental accounting and budgeting reform at local authority in indonesia; an institutionalist perspective", a PhD Dissertation in School of Management, University Sains Malaysia. 2009, unpublished. Accessed on 17/12/2011

[2] A. Farazmand, (Editor), "Sound governance; policy and administrative innovations", 2004, Praeger Publisher, London, UK.

[3] A. Yumarma, "Unity in diversity; a philosophical and ethical study of the javanese concept of keselarasan", 1996, Editrice Pontificia Universita Gregoriana , Roma.

[4] B.H.M. Vlekke, "Nusantara; a history of indonesia", 1965, Harvard University Press.

[5] C. Pelras, "The bugis; the peoples of south-east asia and the pacific", 1996, Blackwell Publishers Ltd, Oxford.

[6] C. Pelras, "Patron client ties among the bugis and makassarese of south sulawesi", Bijdragen tot de Taal-, Land- en Volkenkunde, Leiden, pp.393-432 vol.156,no: 3, 2000.

[7] I. Caldwel, "Power, state and society among the pre-islamic bugis", Bijdragen tot de Taal-, Land- en Volkenkunde, Leiden, pp. 394-421, vol 151, no: 3, 1995.

[8] J. F. Springer, "Empirical theory and development administration: prologues and promise", Public Administration Review, pp. 636-641, vol. 36, no.6. December 1976.

[9] K. Green, "Decentralization and good governance: the case of indonesia”, Munich Personal RePEc Archive (MPRA), 2005, paper No. 18097.

[10] G.Gusnawaty, "Masyarakat madani dalam lontara'; beberapa konsep pembinaan masyarakat sulawesi selatan (Civil society in lontara', some empowerment community concepts in south sulawesi). Research report based on cooperation between the Provincial Government of South Sulawesi and Faculty of Literature, Hasanuddin University, 2000 Makassar.

[11] H.A. Mattulada, "Latoa; suatu lukisan analisis terhadap antropologi politik orang bugis (Latoa; a descriptive analysis of political anthropology of buginese)",1985, Gadjah Mada University Press, Yogyakarta.

[12] H.A. Mattulada, "Sejarah, masyarakat, dan kebudayaan sulawesi selatan (history, society and culture of south sulawesi)", 1998, Hasanuddin University Press, Ujung Pandang

[13] M.R. Rutgers, "Traditional flavor; the different sentiments in european and american administrative thought", Administration and Society, pp. 220-244, vol. 33 no. 2, May 2001.

[14] M. S. Haque, "Theory and practice of public administration in southeast asia: traditions, directions, and impacts". International Journal of Public Administration, pp: 1297-1326, vol. 30, 2007

[15] M.H.A.S.Kumara and W.S Handapangoda, "New public management; the level of preparedness and implementation. a study based on the sri lankan context", Journal of Administration and Governance, pp. vol 3. No.2, 2008

[16] M. Painter and B.G. Peters, "Tradition and public administration", 2010, Palgrave Macmillan, London.

[17] O. Koike, "New public management in japan and southeast asian countries: a magic sword for governance reform?", a paper was presented at the IIAS/Japan Joint Panel on Public Administration, Bologna, Italy, June 21, 2000.

[18] S. Koolhof, "La galigo'; bugis encyclopedia and its growth”, Bijdragen tot de Taal-, Land- en Volkenkunde, Leiden, pp. 362-387, vol. 155, no: 3, 1999. 